\title{
Perbandingan Kapasitas Pesan pada Steganografi DCT Sekuensial dan Steganografi DCT F5 dengan Penerapan Point Operation Image Enhancement
}

\author{
Dian Hafidh Zulfikar*1, Agus Harjoko ${ }^{2}$ \\ ${ }^{1}$ Prodi S2/S3 Ilmu Komputer, FMIPA UGM, Yogyakarta \\ ${ }^{2}$ Jurusan Ilmu Komputer dan Elektronika, FMIPA UGM, Yogyakarta \\ e-mail: *1dyan.hz180@gmail.com, ${ }^{2}$ aharjoko@ugm.ac.id
}

\begin{abstract}
Abstrak
Proses penyisipan pesan pada steganografi pada kawasan DCT umumnya dilakukan pada nilai DCT hasil proses kuantisasi yang memiliki nilai selain 0, ini berhubungan dengan sebaran keberagaman pixel pada citra. Penerapkan point operation image enhancement (POIE) berupa histogram equalization, contrast stretching, brigthening serta gamma correction pada citra penampung sangat berkaitan dengan histogram citra. Parameter uji yang digunakan yaitu banyaknya bit pesan yang mampu ditampung, nilai PSNR dan MSE, serta nilai koefisien DCT hasil kuantisasi.

Berdasarkan hasil pengujian yang telah dilakukan didapatkan beberapa kesimpulan yaitu kapasitas pesan pada steganografi DCT sekuensial lebih besar dibandingkan dengan steganografi DCT F5 baik sebelum penerapan POIE maupun setelah penerapan POIE, kualitas citra stego pada steganografi DCT F5 lebih baik dibandingkan dengan steganografi DCT sekuensial baik sebelum penerapan POIE maupun setelah penerapan POIE, baik steganografi DCT F5 maupun steganografi DCT sekuensial sama-sama tidak memiliki ketahanan terhadap manipulasi terhadap citra stego.
\end{abstract}

Kata kunci-Steganografi, domain DCT, citra penampung, kapasitas pesan, kualitas citra, point operation image enhancement, steganografi DCT sekuensial, steganografi DCT F5.

\begin{abstract}
Steganographic process on the DCT transform is generally done on the value of DCT quantization process results that have a value other than 0 , this relates to the distribution of the diversity of pixels in the image. Applying point operation of image enhancement (POIE) in the form of histogram equalization, contrast stretching, brigthening and gamma correction on the image of the reservoir is associated with the image histogram. Test parameters used is the number of bits that can be accommodated message, PSNR and MSE value, and the value of DCT coefficients quantization results.

Based on test results that have to be got several conclusions that capacity steganographic message on DCT sequential greater than the DCT F5 steganography either before or after application of the application POIE, stego image quality on DCT steganography F5 better than the sequential DCT steganography well before the application POIE and after application of POIE, both F5 and steganography steganography DCT DCT sequential equally resistant to manipulation of stego image.
\end{abstract}

Keywords-Steganography, DCT domain, cover image, messaging capacity, image quality, POIE, sequential DCT steganography, steganography DCT F5.

Received May 18 ${ }^{\text {th }}, 2015$; Revised January $1^{\text {st }}$, 2016; Accepted January $20^{\text {th }}, 2016$ 


\section{PENDAHULUAN}

Steganografi pada media digital digunakan untuk mengekploitasi keterbatasan kekuatan sistem indera penglihatan dan pendengaran manusia, pada citra banyak cara digunakan untuk menyembunyikan informasi. Penelitian steganografi berdasarkan domain pada citra dibagi menjadi dua yaitu domain spasial dan domain transformasi[1], steganografi pada domain transformasi masih lebih baik dibanding pada domain spasial $[2,3]$. Teknik steganografi pada domain transformasi dilakukan dengan menyisipkan pesan dengan memodulasi koefisien dalam sebuah domain tranformasi, seperti pada Discrete Cosine Tranform (DCT) yang digunakan pada kompresi JPEG[3].

Ada beberapa penelitian algoritma steganografi yang mendasarkan teknik penyisipanya menggunakan transformasi DCT[2,3], secara umum proses penyisipan pesan pada kawasan det dilakukan dengan menyisispkan pesan rahasia pada LSB diarea koefisien DCT hasil kuantisasi secara berurutan atau sekuensial[4]. Berbeda pada kebanyakan proses steganografi pada kawasan dct, pada steganografi dct F5 menggunakan metode baru dalam cara penggantian LSB pada koefisien DCT dengan data pesan, dimana F5 tidak mengganti koefisien DCT namun mengurangi bit koefisien DCT dengan data pesan[5].

Konsep penyisipan pesan pada citra sebenarnya adalah proses mengganti nilai bit pesan dengan nilai pixel yang ada pada citra sedemikian sehingga pesan yang disisipkan mampu tersamarkan dalam nilai pixel citra, sehingga dapat memanipulasi keterbatasan visual manusia[6]. Suatu citra dengan nilai kontras yang rendah akan memiliki histogram yang cenderung kurang beragam dengan kata lain nilai pixel yang dihasilkan kurang beragam[7], selain itu umumnya citra yang memiliki detail yang tinggi akan memiliki lebih banyak nilai koefisien DCT selain nol (0) yang lebih banyak[8]. Image enhancement memiliki arti mempertinggi atau meningkatkan kualitas citra dengan metode-metode tertentu [9]. Perbaikan terhadap citra dapat dilakukan dengan beberapa operasi diantara yaitu operasi titik (point operation), operasi spasial (spasial operation), operasi geometri (geometric operation) dan operasi aritmatik (arithmatic operation)[10]. Operasi titik sangat berkaitan dengan histogram citra, dimana histogram citra menunjuk pada histogram dari nilai intensitas pixel serta menampilkan banyaknya pixel dalam suatu citra yang dikelompokkan berdasarkan level intensitas pixel yang berbeda[11].

Hipotesa dari penelitian ini dengan penerapan proses image enhancement terutama dengan beberapa teknik operasi titik pada citra sebelum proses penyisipan pesan rahasia, diharapkan dapat meningkatkan jumlah pesan rahasia yang akan disisipkan karena citra penampung akan mengalami proses perbaikan. Penilaian sebuah algoritma steganografi yang baik dapat dinilai dari beberapa faktor yaitu imperceptibility keberadaan pesan dalam media penampung tidak dapat dideteksi, fidelity yaitu kualitas media penampung setelah ditambahkan pesan tidak jauh berbeda dengan kualitas media penampung sebelum ditambahkan pesan, recovery yaitu pesan rahasia yang telah disisipkan dalam media penampung harus dapat diungkap kembali, dan robustness yaitu pesan yang disembunyikan harus tahan terhadap berbagai operasi manipulasi yang dilakukan pada media penampung[11].

Penelitian ini mencoba untuk membandingkan terutama dari segi kapasitas pesan , kualitas dan ketahanan citra yang dihasilkan dari kedua algoritma steganografi citra berbasis domain transformasi DCT yaitu metode DCT secara sekuensial, dan metode DCT dengan metode F5 (subtraksi), dengan penerapan teknik proses Image Enhancement terutama operasi titik (point operation) berupa histogram equalization, contrast stretching, brigthening serta gamma correction pada citra penampung sebelum disisipi pesan.

\subsection{Data Penelitian}

\section{METODE PENELITIAN}

Sumber data dalam penelitian ini ialah file citra digital yang berasal dari sumber online yaitu http://sipi.usc.edu/database/database.php dari USC Universitas Southern California serta beberapa sumber lainya. Dimana citra akan dinormalisasi dengan dimensi 128 x 128 pixel.

IJCCS Vol. 10, No. 1, January 2016: $35-46$ 
2. 2 Steganografi pada domain Discrete Cosine Transform (DCT)

Pada format gambar JPEG, masing-masing komponen warna menggunakan transformasi DCT (discrete cosine transform) untuk mentransformasi blok-blok gambar $8 \mathrm{x} 8$ pixel kedalam 64 masing-masing koefisien DCT. Koefisien-koefisien DCT tersebut adalah $F(u, v)$ dari suatu blok $8 \times 8$ dari citra pixel $f(x, y)$ dinyatakan pada persamaan $(1)$ :

$$
F(u, v)=\frac{1}{4} C(u) C(v)\left[\sum_{x=0}^{7} \sum_{y=0}^{7} f(x, y) \cos \frac{(2 x+1) u \pi}{16} \cos \frac{(2 y+1) v \pi}{16}\right]
$$

Pada persamaan diatas $F(u, . v)$ berbentuk matriks 2-dimensi 8x8 dimana:

$\mathrm{u}, \mathrm{v}, \mathrm{x}, \mathrm{y}=0,1,2, \ldots, 7$

$\mathrm{x}, \mathrm{y}$ adalah koordinat spatial dari domain asal.

$\mathrm{u}, \mathrm{v}$ adalah koordinat frekuensi pada domain transformasi atau koefisien-koefisien DCT.

$C(u), C(v)=1 / \sqrt{2}$ Untuk u,v $=0$

$C(u), C(v)=1$, untuk lainya.

Selanjutnya adalah kuantisasi, proses kuantisasi diterapkan pada keluaran proses DCT. Kuantisasi dilakukan dengan cara membagi keluaran proses DCT dengan suatu nilai yang ditetapkan dalam matriks kuantisasi. Proses kuantisasi dilakukan dengan persamaan (2) :

$$
F_{Q}(u, v)=\text { Round }\left(\frac{F[u, v]}{q[u, v]}\right)
$$

dimana :

$(q[u, v])=$ tabel kuantisasi

Gambar 1 merupakan tabel kuantisasi komponen luminance dan chrominance standar JPEG.

\begin{tabular}{|rrrrrrrr|}
\hline 16 & 11 & 10 & 16 & 24 & 40 & 51 & 61 \\
12 & 12 & 14 & 19 & 26 & 58 & 60 & 55 \\
14 & 13 & 16 & 24 & 40 & 57 & 69 & 56 \\
14 & 17 & 22 & 29 & 51 & 87 & 80 & 62 \\
18 & 22 & 37 & 56 & 68 & 109 & 103 & 77 \\
24 & 35 & 55 & 64 & 81 & 104 & 113 & 92 \\
49 & 64 & 78 & 87 & 103 & 121 & 120 & 101 \\
72 & 92 & 95 & 98 & 112 & 100 & 103 & 99 \\
\hline
\end{tabular}

\begin{tabular}{|llllllll|}
\hline 17 & 18 & 24 & 47 & 99 & 99 & 99 & 99 \\
18 & 21 & 26 & 66 & 99 & 99 & 99 & 99 \\
24 & 26 & 56 & 99 & 99 & 99 & 99 & 99 \\
47 & 66 & 99 & 99 & 99 & 99 & 99 & 99 \\
99 & 99 & 99 & 99 & 99 & 99 & 99 & 99 \\
99 & 99 & 99 & 99 & 99 & 99 & 99 & 99 \\
99 & 99 & 99 & 99 & 99 & 99 & 99 & 99 \\
99 & 99 & 99 & 99 & 99 & 99 & 99 & 99 \\
\hline
\end{tabular}

\section{Gambar 1 Tabel kuantisasi luminance dan chrominance}

LSB dari koefisien DCT yang terkuantisasi dapat digunakan sebagai bit-bit redundant untuk menyisipkan pesan rahasia. Pada tahap ini, koefisien DC dari tiap blok disatukan untuk memasuki tahap entropy coding, teknik DPCM (differential pulse code modulation) digunakan karena nilai-nilai koefisien DC antar blok tidak berbeda jauh[12]. Gambar 2 menjelaskan proses DPCM yang diterapkan pada koefisien DC.

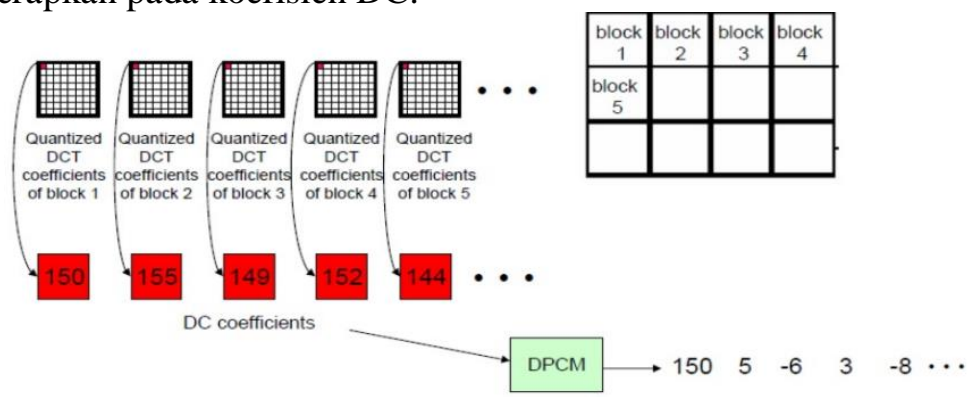

Gambar 2 Differential Pulse Code modulation[10]

\section{Entropy coding pada koefisien DC}

Koefisien DC yang sudah melalui tahap DPCM kemudian dikompresi menggunakan metode huffman, tetapi sebelumnya deretan angka tersebut akan dirubah bentuknya menjadi pasangan-pasangan (size,amplitude) dimana size menyatakan jumlah bit 
yang diperlukan untuk merepresentasikan jumlah angka DPCM dan amplitude menyatakan angka tersebut dalam bit[12]. Berikut Tabel 1 yang menyatakan hubungan antara size dan amplitude-nya:

Tabel 1 Hubungan size,amplitude dan number

\begin{tabular}{|c|c|c|}
\hline Size & Amplitude Number & Number \\
\hline 1 & 0,1 & $-1,1$ \\
\hline 2 & $00,01,10,11$ & $-3-2,2,3$ \\
\hline 3 & $000, \ldots, 011,100, \ldots, 111$ & $-7, \ldots,-4,4, \ldots, 7$ \\
\hline 4 & $0000, \ldots, 0111,1000, \ldots, 1111$ & $-15, \ldots,-8,8, \ldots, 15$ \\
\hline$\ldots$ & $\ldots$ & $\ldots$ \\
\hline 10 & $0000000000, \ldots, 0111111111,1000000000, \ldots, 1111111111$ & $-1023, \ldots,-512,512, \ldots, 1023$ \\
\hline
\end{tabular}

Gambar 3 merupakan contoh proses huffman pada koefisien DC.

$$
\begin{aligned}
& 150_{(10)}=10010110_{(2)} \quad 5_{(10)}=101_{(2)} \quad 6_{(10)}=110_{(2)} \quad 3_{(10)}=11_{(2)} \quad 8_{(10)}=1000_{(2)} \\
& \therefore 150 \rightarrow(8,10010110) \quad \therefore 5 \rightarrow(3,101) \quad \therefore-6 \rightarrow(3,001) \quad \therefore 3 \rightarrow(2,11) \quad \therefore-8 \rightarrow(4,0111) \\
& \text { (SIZE, AMPLITUDE): } \underbrace{(8,10010110)}_{\text {Huffman }}
\end{aligned}
$$

Gambar 3 Proses entropy encoding pada koefisien DC

\section{Zig-zag scanning}

Pada proses zig-zag scanning ini koefisien DCT terkuantisasi yang bernilai nol cenderung terbaca secara berurutan. Gambar 4 merupakan contoh proses zig-zag scan.

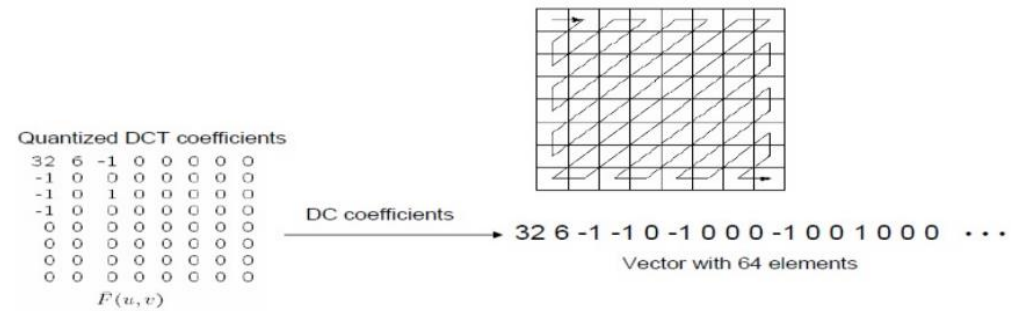

Gambar 4 Proses zig-zag scan

\section{Run Length Code}

RLC (Run Length Code) yaitu proses serangkaian simbol yang berurutan dikodekan menjadi suatu kode yang terdiri dari simbol tersebut dan jumlah pengulanganya. RLC mempunyai dua simbol yaitu[13]:

Symbol $1 \quad$ Symbol 2

(RUNLENGTH, SIZE) (AMPLITUDE)

\section{Entropy coding pada koefisien AC}

Koefisien AC yang sudah melalui tahap RLC juga dikompresi menggunakan kompresi huffman, pasangan-pasangan sebelumnya diubah lagi menjadi pasangan-pasangan (runlength, size, amplitude). Dalam hal ini yang mengalami kompresi huffman hanya runlength dan size-nya seperti pada koefisien DC. Lebih lanjut dijelaskan dalam Gambar 5:

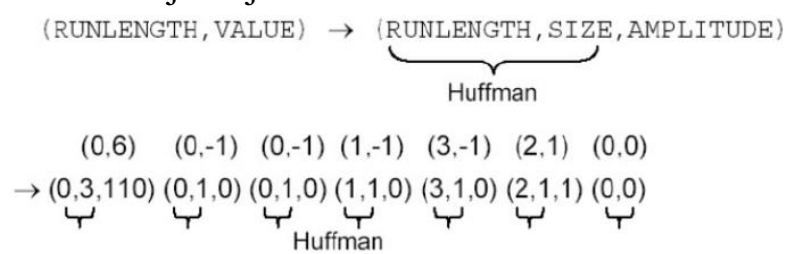

Gambar 5 Proses Entropy Encoding pada koefisien AC[10]

\subsection{Steganografi pada domain DCT dengan metode sekuensial}

Proses steganografi pada domain DCT dilakukan secara sekuensial dimana algoritma proses embeddingnya dilakukan secara berurutan/sekuensial dengan mengganti LSB dari 
koefisien-koefisien DCT dengan data pesan rahasia. Pada proses penyisipanya, perubahan pada koefisien AC dilakukan sedemikian rupa sehingga dapat menghasilkan citra yang tidak jauh berbeda dari citra aslinya. Dalam hal ini ada tiga kasus yang dapat terjadi, pertama ketika data pada pesan rahasia dan LSB pada koefisien AC adalah sama maka tidak perlu ada perubahan yang terjadi. Kedua ketika LSB pada koefisien AC adalah 0 dan data pesan rahasia adalah 1, maka nilai koefisien AC diganti dengan nilai 1, selanjutnya yang ketiga ketika LSB pada koefisien AC bernilai 1 dan nilai pada data pesan rahasia adalah 0, maka nilai koefisien AC diganti dengan nilai $0[13]$.

\subsubsection{Kapasitas pesan pada steganografi dct sekuensial}

Kapasitas pesan pada steganografi DCT sekuensial divisualisasikan dengan fungsi progress bar, terdapat variabel totalmax yang merupakan jumlah total data unit yang disebut MCU (Minimum Coded Units), MCU sendiri merupakan blok 8 x 8 pixel citra input yang akan dilakukan proses kompresi pada tahapan pembentukan citra Jpeg[], juga terdapat variabel modified yang merupakan jumlah koefisien AC yang mengalami perubahan akibat penyisipan pesan. Dalam algoritmanya terdapat variabel yang menampung data pesan yang akan disisipkan yaitu compdataarray, perhitungan kapasitas pesan sendiri dilakukan dengan membaca variabel yang menampung data pesan yang disisipkan.

\subsection{Steganografi pada domain DCT dengan metode F5}

Untuk menggantikan cara penggantian LSB koefisien DCT dengan data pesan, F5 mengurangi bit koefisien DCT dengan data pesan[5].

Proses penyisipan pesan dalam citra mengunakan algoritma F5 dapat dilihat dalam Gambar 6

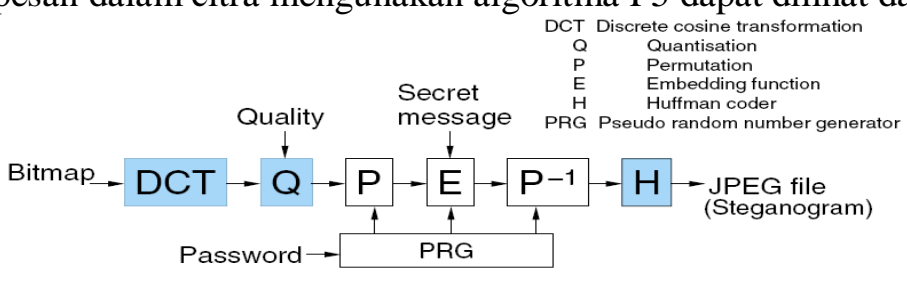

Gambar 6 Proses penyisipan pesan metode F5[10].

Dalam proses embedding pesan dalam citra menggunakan algoritma F5 ini pertama-tama dimasukkan (input) file citra dengan ukuran 128 x 128 pixel. Setelah itu masukkan password atau shared secret sebagai kunci steganografi. Setelah itu ambil pixel dari citra tersebut, kemudian lakukan perhitungan DCT sesuai dengan persamaan (1) untuk memperoleh koefisien DCT atau domain frekuensinya serta hasil tabel kuantisasinya. Inisialisasi PRNG dengan password yang telah dimasukkan. Setelah itu dilakukan permutasi pada koefisien DCT, lalu dilakukan proses embedding bit data pesan ke dalam koefisien DCT yang telah dipermutasikan. Setelah proses embedding selesai, lakukan invers permutasi terhadap koefisien DCT yang telah disisipkan pesan. Sehingga didapatkan hasil berupa stego image. Selanjutnya dilakukan huffman coding untuk mengkompresi citra sehingga output citra atau stego image merupakan citra dengan format JPEG $(*$ *.jpg).

\subsubsection{Kapasitas pesan pada steganografi dct F5}

Perhitungan kapasitas pesan yang dapat disisipkan pada steganografi F5 dilakukan dengan menghitung nilai total koefisien DCT dikurangi dengan koefisien DC, koefisien DCT bernilai nol, serta koefisien DCT bernilai nol hasil proses shrinked. Shrinked terjadi ketika dalam proses pengurangan atau penambahan koefisien DCT dengan data pesan, nilai koefisien DCT menjadi nol, proses Shrinked terjadi akan terjadi tergantung dari pesan yang akan disisipkan, sehingga dalam hal ini kapasitas pesan yang dihitung adalah perkiraan kapasitasnya. Formula untuk menghitung kapasitas pesan pada steganografi F5 menurut [5] yaitu: Kapasitas=\#DCT $\left(\right.$ total) $-\# \mathrm{DCT}_{(-1)}-\# \mathrm{DCT}_{(1)}-\mathrm{DCT}_{(0)}-\# \mathrm{DCT}_{(\mathrm{dc})}$ 
Dimana \#DCT $\mathrm{T}_{\text {(total }}=\mathrm{Jumlah}$ total koefisien dct

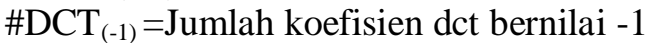

$\# \mathrm{DCT}_{(1)}=\mathrm{Jumlah}_{\text {koefisien det bernilai } 1}$

$\# \mathrm{DCT}_{(0)}=\mathrm{Jumlah}_{\text {koefisien dct bernilai } 0}$

$\# \mathrm{DCT}_{(\mathrm{dc})}=\mathrm{Jumlah}_{\text {koefisien dct bernilai dc }}$

\subsection{Point Operation Image Enhancement}

Histogram citra sangat berkaitan dengan berbagai teknik pengolahan citra, terutama metode-metode yang tergolong dalam operasi titik(POIE).

\subsubsection{Histogram Equalization}

Yang dimaksud Histogram Equalization adalah mengubah derajat keabuan suatu pixel $(r)$ dengan dengan derajat keabuan yang baru $(s)$ dengan suatu fungsi transformasi $T$, yang dalam hal ini $s=T(r)$. Dua sifat yang dipertahankan dalam tranformasi ini [9]: adalah :

- Nilai $s$ merupakan pemetaan 1 ke 1 dari $r$, ini untuk menjamin representasi nilai yang tetap. Ini berarti $r$ dapat diperoleh kembali dari $s$ dengan tranformasi invers yang ditunjukkan pada persamaan (3):

$$
r=T^{-1}(s), \quad 0 \leq \mathrm{s} \leq 1
$$

- Untuk $0 \leq r_{i} \leq 1$, maka $0 \leq T(r) \leq 1$. Ini untuk menjamin pemetaan $T$ konsisten pada rentan nilai yang diperbolehkan.

\subsubsection{Brightening}

Kecerahan gambar dapat dilakukan dengan cara menambahkan (atau mengurangkan) sebuah konstanta dari setiap pixel di dalam citra.

Secara matematis proses brightness ditulis sebagai berikut pada persamaan (4):

$$
\text { - } \mathrm{f}(\mathrm{x}, \mathrm{y})^{\prime}=\mathrm{f}(\mathrm{x}, \mathrm{y})+\mathrm{b}
$$

\subsubsection{Gamma Correction}

Gamma mendefinisikan hubungan antara nilai numerik pixel dengan pencahayaan yang sebenarnya. Bentuk umum dari transformasi gamma ditunjukkan pada persamaan (5):

$$
U^{\prime}=255 \times\left(\frac{U}{255}\right)^{\frac{1}{\gamma}}
$$

Dengan $U$ ' dan $U$ berturut-turut adalah citra setelah dan sebelum mengalami koreksi gamma, sedangkan $\gamma$ adalah faktor koreksi gamma, dengan kisaran nilai $0<\gamma<1$. Bila $\gamma=1$ maka hasil transformasi akan sama dengan citra masukan. Semakin kecil faktor koreksi maka citra output akan semakin terang dan semakin tinggi faktor koreksi maka citra output akan mendekati citra asli[9].

\subsubsection{Contrast Stretching}

Peregangan kontras (sering disebut proses normalisasi) adalah teknik perbaikan citra sederhana yang mencoba untuk meningkatkan kontras pada citra dengan proses peregangan ( Stretching ) kisaran intensitas nilai yang dikandungnya menjadi kisaran nilai baru yang diinginkan. Pada perenggangan kontras, setiap pixel pada citra $U$ ditransformasi dengan menggunakan fungsi pada persamaan (6).

$$
P o(i, j)=P i(i, j)-c\left(\frac{b-c}{d-c}\right)+a
$$

Variabel $P o(i, j)$ dan $P i(i, j)$ berturut-turut pixel sesudah dan sebelum ditransformasi pada koordinat $(i, j)$,.Bila nilai pixel lebih kecil dari 0 maka akan dijadikan 0 dan bila lebih besar dari 255 akan diset 255[9]. 


\subsection{Entropi Citra}

Entropi citra merupakan salah satu fitur yang dapat dihitung pada matrik GLCM (Gray Level Co-occurrence matrix). Matrix GLCM dihitung dari nilai pixel yang berpasangan dan memiliki nilai intensitas tertentu. Misalkan d adalah jarak antara dua pixel yaitu $\left(\mathrm{x}_{1}, \mathrm{y}_{1}\right)$ dan $\left(\mathrm{x}_{2}, \mathrm{y}_{2}\right)$ dan $\Theta$ tetha didefinisikan sebagai sudut antara keduanya, maka matrix GLCM merupakan distribusi spasial dari $\mathrm{P}_{\mathrm{d} \Theta}(\mathrm{i}, \mathrm{j})$. Fitur Entropi sendiri merupakan salah satu fitur yang digunakan untuk mengukur kompleksitas atau keacakan suatu citra. Nilai entropi akan bernilai tinggi ketika citra tidak seragam, sebaliknya akan bernilai rendah ketika kompleksitas citra semakin seragam [8].

\subsection{PSNR dan MSE}

Untuk menentukan PSNR, terlebih dahulu harus ditentukan nilai MSE (Mean Square Error). MSE adalah nilai error kuadrat rata-rata antara citra cover dengan stego image, secara matematis dapat dirumuskan pada persamaan (7):

$M S E=\frac{1}{M, N} \sum_{Y=1}^{M} \sum_{X=1}^{N}\left[I(x, y)-I^{\prime}(x, y)\right]^{2}$

Dimana :

MSE = Nilai Mean Square Error citra steganografi

$\mathrm{M}=$ Panjang citra stego (dalam pixel)

$\mathrm{N}$ = Lebar citra stego (dalam pixel)

$\mathrm{I}(\mathrm{x}, \mathrm{y})=$ nilai piksel dari citra cover

$\mathrm{I}^{\prime}(\mathrm{x}, \mathrm{y})=$ nilai piksel pada citra stego

Setelah diperoleh nilai MSE maka nilai PSNR dapat dihitung dari kuadrat nilai maksimum dibagi dengan MSE. Secara matematis, nilai PSNR dirumuskan pada persamaan (8). PSNR $=10 \log _{10}\left(\frac{\text { MAXi }^{2}}{\text { MSE }}\right)$

Dimana:

MSE $=$ nilai MSE .

$\mathrm{MAXi}=$ nilai maksimum dari pixel citra yang digunakan

Semakin rendah Nilai MSE maka akan semakin baik, dan semakin besar nilai PSNR maka semakin baik kualitas citra steganografi. Nilai PSNR yang wajar pada perbandingan dua berkas citra adalah $30-50 \mathrm{~dB}[10]$.

\subsection{Rancangan Umum Sistem}

Gambaran sistem secara umum yang dilakukan pada penelitian ini seperti ditunjukkan pada Gambar 7

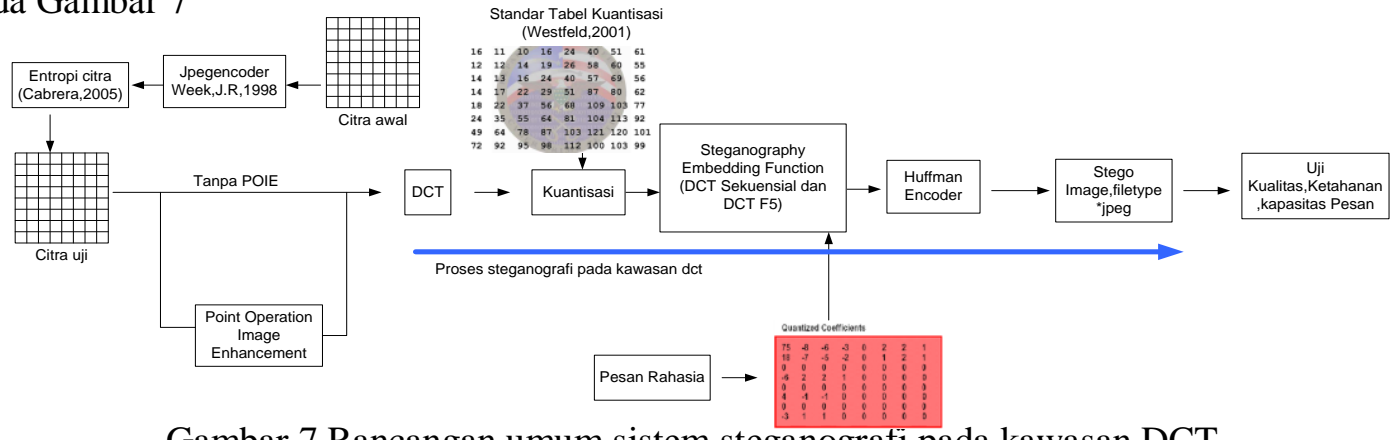

Gambar 7 Rancangan umum sistem steganograti pada kawasan DCT

Pada Gambar 7 dijelaskan Pada proses embedding, pertama-tama citra penampung berupa citra normal sebelum diterapkan proses POIE akan disisipi dengan pesan rahasia menggunakan metode DCT secara sekuensial, dan metode F5. Kedua metode ini masing-masing akan menghasilkan stego image (citra setelah disisipi pesan). Selanjutnya citra penampung yang telah diterapkan proses POIE juga akan disisipi pesan rahasia menggunakan metode DCT sekuensial dan metode F5. Stego image hasil proses POIE ataupun yang tidak akan dilakukan proses perbandingan kapasitas maksimum pesan, kualitas dan ketahanannya. 


\subsection{Rancangan Pengujian}

\subsubsection{Pengujian Kapasitas Pesan Rahasia}

Pada Gambar 8 dijelaskan proses percobaan yang dilakukan, pada percobaan pertama citra penampung sebelum diterapkan proses POIE dilakukan penyisipan pesan sampai maksimum, hal ini dilakukan baik pada steganografi dct sekuensial maupun det f5,selanjutnya pada percobaan kedua citra penampung akan dilakukan proses POIE terlebih dahulu sebelum disisipkan pesan,hal ini juga dilakukan pada kedua algoritma,kemudian dihitung kapasitas maksimal pesan yang mampu disisipkan,selanjutnya percobaan pertma dan kedua dibandingkan hasil yang didapatkan.

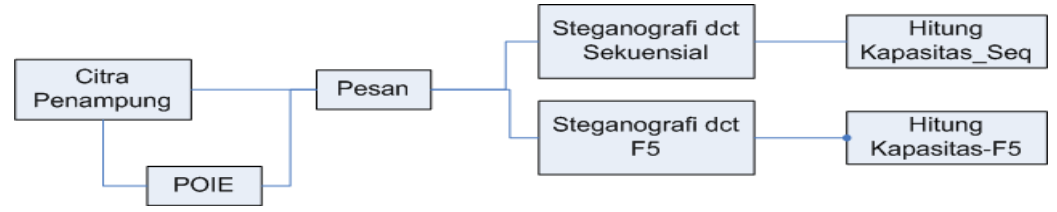

Gambar 8 Skenario pengukuran kapasitas maksimum pesan

\subsubsection{Pengujian Kualitas citra}

Pada Gambar 9 dijelaskan proses pengukuran kualitas citra stego. Pada percobaan pertama citra penampung sebelum penerapan POIE akan disisipi pesan baik pada steganografi dct sekuensial ataupun F5 kemudian masing-masing algoritma akan menghasilakan stego image, selanjutnya stego image yang dihasilkan dibandingkan nilai PSNR nya dengan citra penampung sebelum disisipi pesan baik pada steganografi dct sekuensial maupun dct f5. Proses yang sama juga dilakukan pada citra penampung setelah penerapan POIE, kemudian dibandingkan hasil percobaan pertama dan kedua.

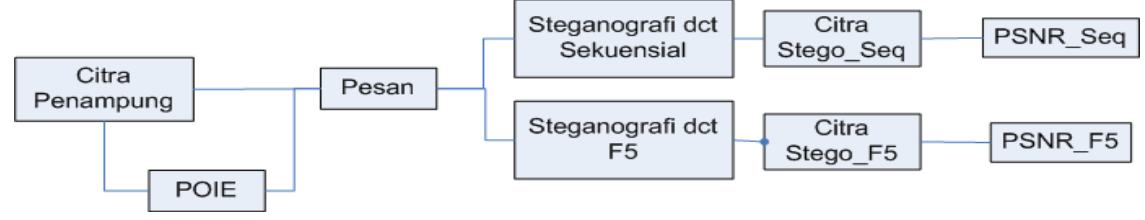

Gambar 9 Skenario pengukuran kapasitas maksimum pesan

\subsubsection{Pengujian Ketahanan citra stego}

Pengujian penyerangan teknik steganografi dilakukan dengan merusak data citra yang menjadi media stego serta ketahanan dari teknik steganografi tersebut terhadap manipulasi yang dilakukan pada media stego tersebut. Gambar 10 dijelaskan bagaimana proses pengukuran ketahanan citra stego setelah dilakukan distorsi pada citra stego.

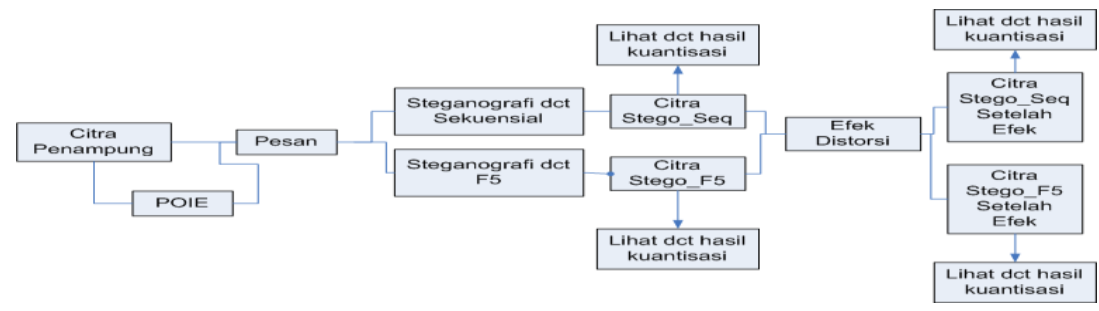

Gambar 10 Skenario pengukuran kapasitas maksimum pesan

\section{HASIL DAN PEMBAHASAN}

\subsection{Berdasarkan kapasitas pesan}

Berikut adalah hasil perhitungan kapasitas pesan dari algoritma steganografi DCT sekuensial dengan DCT F5 pada citra dengan dimensi 128 x 128 pixel.

3.1.1 Hubungan antara kompleksitas citra dengan kapasitas pesan

Gambar 11 menunjukkan grafik perbandingan kapasitas penyisipan citra asli berdasarkan kompleksitas citra, terlihat kapasitas citra cenderung meningkat seiring 
meningkatnya kompleksitas citra. Steganografi DCT sekuensial mempunyai kapasitas pesan yang lebih besar yaitu sebesar 11130.67 bit dibandingkan dengan metode yang F5 sebesar 8256.5 bit .

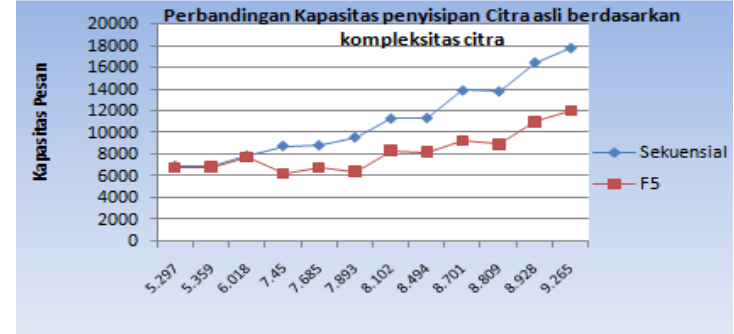

Gambar 11 Perbandingan kapasitas penyisispan citra berdasarkan kompleksitas citra

\subsubsection{Hubungan antara kapasitas citra dengan quality factor citra jpeg}

Pada Tabel 2 ditampilkan data nilai kapasitas pesan berdasarkan besar quality factor yang digunakan, dari hasil yang diperoleh ternyata quality factor mempengaruhi kapasitas pesan yang mampu ditampung pada citra penampung, dimana semakin besar quality factor, semakin besar pula kapasitas pesan yang dapat ditampung, hal ini disebabkan pada quality factor yang rendah menyebabkan citra penampung mengalami proses kompresi yang tinggi, sehingga banyak informasi citra yang dihilangkan, sedangkan pada quality factor yang tinggi, citra penampung mengalami proses kompresi yang rendah, sehingga hanya sedikit informasi yang dihilangkan.

Tabel 2 data nilai kapasitas pesan berdasarkan besar quality factor

\begin{tabular}{|c|c|c|c|c|c|c|c|c|}
\hline \multirow{3}{*}{ No } & \multirow{3}{*}{$\begin{array}{c}\text { Nama Citra } \\
\text { Ori }\end{array}$} & \multirow{3}{*}{$\begin{array}{c}\text { Nilai } \\
\text { Entropy }\end{array}$} & \multicolumn{6}{|c|}{ Kapasitas Penyisipan (bits) } \\
\hline & & & \multicolumn{3}{|c|}{ Sekuensial } & \multicolumn{3}{|c|}{ F5 } \\
\hline & & & Q_30 & Q_50 & $Q_{90}$ & Q_30 & Q 50 & Q_90 \\
\hline 1 & Low1 & 5.297 & 2680 & 3600 & 6904 & 2617 & 3503 & 6814 \\
\hline 2 & Low2 & 5.359 & 2888 & 3936 & 6936 & 2825 & 3842 & 6897 \\
\hline 3 & Low3 & 6.018 & 2152 & 3256 & 7864 & 2074 & 3194 & 7816 \\
\hline$\frac{3}{4}$ & Middle1 & 7.450 & 2488 & 3664 & 8768 & 2210 & 2980 & 6284 \\
\hline 5 & Middle2 & 7.685 & 2560 & 3808 & 8816 & 2402 & 3264 & 6834 \\
\hline 6 & Middle3 & 7.893 & 2768 & 3976 & 9560 & 2299 & 3014 & 6463 \\
\hline 7 & High1 & 8.102 & 3520 & 5024 & 11296 & 3177 & 4273 & 8380 \\
\hline 8 & High2 & 8.494 & 3624 & 5120 & 11352 & 3234 & 4243 & 8252 \\
\hline 9 & High3 & 8.701 & 4576 & 6304 & 13912 & 3767 & 4775 & 9264 \\
\hline 10 & Veryhigh1 & 8.809 & 4776 & 6344 & 13816 & 4385 & 5432 & 8978 \\
\hline 11 & Veryhigh2 & 8.928 & 5088 & 7296 & 16504 & 4391 & 5837 & 11049 \\
\hline 12 & Veryhigh3 & 9.265 & 4664 & 7160 & 17840 & 4076 & 5843 & 12047 \\
\hline \multicolumn{3}{|c|}{ Rata-Rata } & 3482 & 4957.333 & 11130.67 & 3121.417 & 4183.33 & 8256.5 \\
\hline
\end{tabular}

\subsubsection{Hubungan antara penerapan POIE dengan kapasitas pesan}

Pada Tabel 3 didapatkan hasil pada steganografi dct sekuensial setelah penerapan histogram equalization, berdasarkan level kompleksitas citra, citra low mengalami peningkatan yang paling tinggi sebesar $58.04 \%$, peningkatan paling kecil terjadi pada citra veryhigh yaitu sebesar $0.89 \%$, setelah penerapan contrast stretching, citra low mengalami peningkatan yang paling tinggi sebesar $62.62 \%$, sebaliknya terjadi penurunan kapasitas citra pada level middle, high, dan veryhigh, penurunan paling tinggi terjadi pada citra veryhigh sebesar $-40.91 \%$, setelah penerapan brigthening sebesar 50, ternyata semua level mengalami penurunan, penurunan tertinggi terjadi pada level veryhigh sebesar $-25.16 \%$, setelah penerapan gamma correction citra level low mengalami peningkatan paling tinggi sebesar $1.991 \%$, sedangkan peningkatan kapasitas pesan paing rendah terjadi pada level kompleksitas veryhigh sebesar 0.10. Hal yang hampir sama juga terjadi pada penerapan POIE pada steganografi det F5 seperti terlihat pada Tabel 4.

Tabel 3. Rata-rata peningkatan kapasitas pesan berdasarkan kompleksitas citra setelah penerapan POIE pada steganografi dct sekuensial

\begin{tabular}{|c|c|c|c|c|c|}
\hline No & $\begin{array}{c}\text { Kompleksitas } \\
\text { Citra }\end{array}$ & $\mathrm{HE}(\%)$ & $\mathrm{CS}(\%)$ & B_50(\%) & GC_1.25(\%) \\
\hline 1 & Low & 58.04 & 62.62 & -0.94 & 1.99 \\
\hline 2 & Middle & 31.57 & 29.97 & -4.41 & 0.62 \\
\hline 3 & High & 14.62 & -14.30 & -12.20 & 0.38 \\
\hline 4 & Veryhigh & 0.89 & -40.91 & -25.16 & 0.10 \\
\hline
\end{tabular}


Tabel 4 Rata-rata peningkatan kapasitas pesan berdasarkan kompleksitas citra setelah penerapan POIE pada steganografi dct F5

\begin{tabular}{|c|c|c|c|c|c|}
\hline No & Kompleksitas Citra & $\mathrm{HE}(\%)$ & CS & B_50 & G_1.25 \\
\hline 1 & Low & 63.54 & 65.81 & 2.12 & 5.58 \\
\hline 2 & Middle & 33.64 & 26.24 & -4.18 & 2.77 \\
\hline 3 & High & 14.13 & -16.00 & -14.99 & 1.34 \\
\hline 4 & Veryhigh & 1.18 & 0.21 & -30.82 & 0.36 \\
\hline
\end{tabular}

\subsection{Berdasarkan Kualitas Citra}

\subsubsection{Sebelum Penerapan Point Operation Image Enhancement (POIE)}

Berdasarkan data nilai PSNR maupun MSE yang didapatkan data nilai yang menunjukkan secara rata-rata nilai PSNR dan MSE pada steganografi det F5 masih lebih baik sebesar $36.07 \mathrm{db}$ pada nilai PSNR dan 96.32db pada nilai MSE, dibandingkan dengan nilai PSNR dan MSE pada steganografi det sekuensial sebesar 24.99db pada PSNR dan $1233.65 \mathrm{db}$ pada nilai MSE. Berdasarkan kompleksitas citra baik pada steganografi dct sekuensial dan steganografi dct F5 semakin tinggi kompleksitas citra maka semakin baik nilai PSNR dan MSE yang didapatkan. Pada Tabel 5 menunjukkan perbandingan nilai PSNR dan MSE citra asli dengan citra stego sebelum penerapan POIE.

Tabel 5 Perbandingan nilai PSNR dan MSE citra asli dengan citra stego sebelum penerapan POIE

\begin{tabular}{|c|c|c|c|c|c|}
\hline \multirow{2}{*}{ No } & \multirow{2}{*}{ Nama Citra Asli } & \multicolumn{2}{|c|}{ PSNR $(\mathrm{db})$} & \multicolumn{2}{|c|}{ MSE } \\
\hline & & Sekuensial & F5 & Sekuensial & F5 \\
\hline 1 & Low 1.jpg & 22.27 & 32.81 & 1182.05 & 104.41 \\
\hline 2 & Low2.jpg & 23.35 & 34.36 & 1159.20 & 91.79 \\
\hline 3 & Low3.jpg & 23.74 & 34.78 & 1204.55 & 94.83 \\
\hline 4 & Middle1.jpg & 24.19 & 35.31 & 1248.36 & 96.58 \\
\hline 5 & Middle2.jpg & 24.55 & 35.40 & 1287.13 & 105.79 \\
\hline 6 & Middle3.jpg & 25.37 & 36.12 & 1184.31 & 99.72 \\
\hline 7 & High1.jpg & 25.37 & 36.61 & 1321.85 & 99.40 \\
\hline 8 & High2.jpg & 26.20 & 37.04 & 1210.09 & 99.71 \\
\hline 9 & High3.jpg & 26.40 & 37.37 & 1286.03 & 102.94 \\
\hline 10 & Veryhigh1.jpg & 26.73 & 38.52 & 1241.35 & 82.13 \\
\hline 11 & Veryhigh2.jpg & 26.72 & 38.52 & 1245.30 & 82.28 \\
\hline & Rata-Rata & 24.99 & 36.07 & 1233.656 & 96.32 \\
\hline
\end{tabular}

\subsubsection{Setelah Penerapan Point Operation Image Enhancement (POIE)}

Pada Tabel 6 Perbandingan Nilai PSNR pada citra asli dengan citra stego setelah penerapan POIE.

Tabel 6 Perbandingan Nilai PSNR pada citra asli dengan citra stego setelah penerapan POIE

\begin{tabular}{|c|c|c|c|c|c|c|c|c|c|}
\hline \multirow{3}{*}{ No } & \multirow{3}{*}{ Nama Citra ori } & \multicolumn{8}{|c|}{ PSNR } \\
\hline & & \multicolumn{4}{|c|}{ Sekuensial } & \multicolumn{4}{|c|}{ F5 } \\
\hline & & $\mathrm{HE}$ & $\mathrm{CS}$ & B_50 & GC_1.25 & $\mathrm{HE}$ & CS & B_50 & GC_1.25 \\
\hline 1 & Low1.jpg & 26.81 & 29.49 & 26.49 & 25.59 & 37.40 & 36.71 & 37.85 & 35.61 \\
\hline 2 & Low2.jpg & 26.65 & 29.43 & 26.42 & 23.86 & 37.81 & 36.62 & 37.87 & 35.35 \\
\hline 3 & Low3.jpg & 26.64 & 28.95 & 26.37 & 24.21 & 37.47 & 36.64 & 37.72 & 35.49 \\
\hline 4 & Middle1.jpg & 26.62 & 29.11 & 26.85 & 25.27 & 37.63 & 36.77 & 38.11 & 36.24 \\
\hline 5 & Middle2.jpg & 26.35 & 29.07 & 26.59 & 25.27 & 37.82 & 37.01 & 37.59 & 36.62 \\
\hline 6 & Middle3.jpg & 26.21 & 28.65 & 26.69 & 25.58 & 37.64 & 36.38 & 37.96 & 36.64 \\
\hline 7 & High1.jpg & 14.70 & 29.30 & 26.93 & 25.74 & 38.37 & 36.49 & 38.07 & 37.14 \\
\hline 8 & High2.jpg & 16.70 & 28.62 & 27.29 & 26.42 & 38.46 & 36.60 & 38.15 & 37.27 \\
\hline 9 & High3.jpg & 18.99 & 28.94 & 27.70 & 26.58 & 38.17 & 37.07 & 38.46 & 38.69 \\
\hline 10 & Veryhigh1.jpg & 22.85 & 26.63 & 28.06 & 26.65 & 38.67 & 38.35 & 38.33 & 38.43 \\
\hline 11 & Veryhigh2.jpg & 25.53 & 26.44 & 28.75 & 26.55 & 38.70 & 38.12 & 38.72 & 38.37 \\
\hline & Rata-Rata & 23.45 & 28.60 & 27.10 & 25.61 & 38.01 & 36.97 & 38.08 & 36.89 \\
\hline
\end{tabular}

Dari hasil yang didapatkan, dibandingkan dengan kualitas citra sebelum penerapan POIE dan setelah penerapan POIE, ternyata kualitas citra yang didapatkan tidak terlalu berbeda jauh, ini menunjukkan bahwa penerapan POIE terhadap kualitas citra tidak terlalu berpengaruh signifikan terhadap kualitas citra.

\subsection{Berdasarkan Ketahanan citra}

Berdasarkan hasil yang didapatkan setelah dilakukan ektraksi pesan, tidak ada satupun pesan yang mampu diungkap kembali, hal ini disebabkan setelah penerapan beberapa efek atau ganguan pada citra yang mengandung pesan, menyebabkan berubahnya nilai koefisien DCT serta nilai koefisien DCT hasil kuantisasi yang mana pada nilai tersebutlah pesan disisipkan.

IJCCS Vol. 10, No. 1, January 2016: $35-46$ 
3.3.1 Sebelum Penerapan Point Operation Image Enhancement (POIE).

Berikut merupakan data hasil ektraksi pada citra stego sebelum penerapan Point Operation Image Enhancement(POIE).

$>$ EFEK ROTASI

Pada Tabel 7 merupakan data hasil proses ektraksi pesan pada steganografi DCT F5 setelah pemberian efek rotasi vertikal. Dari hasil yang didapatkan tidak ada satupun file pesan yang mampu dibaca kembali.

Tabel 7 Hasil Ektraksi DCT F5 setelah efek rotasi

\begin{tabular}{|c|c|c|}
\hline No & Nama Citra Asli & $\begin{array}{c}\text { Hasil ektraksi } \\
\text { (bit) }\end{array}$ \\
\hline 1 & Low1stegoRotation.jpg & Null \\
\hline 2 & Low2stegoRotation.jpg & Null \\
\hline 3 & Low3stegoRotation.jpg & Null \\
\hline 4 & Middle1stegoRotation.jpg & Null \\
\hline 5 & Middle2stegoRotation.jpg & Null \\
\hline 6 & Middle3stegoRotation.jpg & Null \\
\hline 7 & High1stegoRotation.jpg & Null \\
\hline 8 & High2stegoRotation.jpg & Null \\
\hline 9 & Veryhigh1stegoRotation.jpg & Null \\
\hline 10 & Veryhigh2stegoRotation.jpg & Null \\
\hline
\end{tabular}

Pada Tabel 8 merupakan nilai DCT hasil kuantisasi pada steganografi DCT F5 sebelum pemberian efek pada citra high2_stego_f5.jpg.

Tabel 8 Nilai koefisien DCT hasil kuantisasi steganografi DCT F5 sebelum pemberian efek pada citra high2_stego_f5.jpg

\begin{tabular}{|c|c|c|c|c|c|c|c|c|}
\hline Koordinat(x,y) & 0 & 1 & 2 & 3 & 4 & 5 & 6 & 7 \\
\hline 0 & 52 & 0 & -6 & -2 & -4 & 0 & 0 & 0 \\
\hline 1 & 2 & -1 & 3 & 1 & -2 & 0 & 0 & 1 \\
\hline 2 & 0 & 0 & -1 & 0 & 2 & 0 & 0 & 0 \\
\hline 3 & -3 & -3 & -1 & 2 & 0 & 0 & 0 & 1 \\
\hline 4 & -2 & -1 & 1 & 0 & 0 & 0 & 0 & 0 \\
\hline 5 & 0 & -1 & 1 & 0 & 1 & 0 & 0 & 0 \\
\hline 6 & 0 & 0 & 0 & 0 & 0 & 0 & 0 & 0 \\
\hline 7 & 0 & 0 & 0 & 0 & 0 & 0 & 0 & 0 \\
\hline
\end{tabular}

Tabel 9 merupakan nilai det hasil kuantisasi pada blok citra 8 × 8 pixel pada posisi kanan atas pada citra high2_stego_f5_skala.jpg setelah pemberian efek penskalaan pada steganografi dct F5, didapatkan jika dibandingkan dengan nilai det sebelum pemberian efek penskalaan terjadi perubahan nilai det yang dihasilkan

Tabel 9 Perbandingan Nilai DCT hasil kuantisasi setelah pemberian efek penskalaan pada DCT Sekuensial (high2_stego_f5_skala.jpg)

\begin{tabular}{|c|c|c|c|c|c|c|c|c|}
\hline Koordinat(x,y) & 0 & 1 & 2 & 3 & 4 & 5 & 6 & 7 \\
\hline 0 & 53 & -5 & -2 & -5 & -2 & 0 & 0 & 0 \\
\hline 1 & 2 & 1 & 2 & -1 & 0 & 0 & 0 & 0 \\
\hline 2 & -2 & -2 & -1 & 3 & 1 & 0 & 0 & 0 \\
\hline 3 & -3 & -2 & 1 & 0 & 0 & 0 & 0 & 0 \\
\hline 4 & 2 & 1 & 1 & 0 & 0 & 0 & 0 & 0 \\
\hline 5 & 0 & 0 & 0 & 0 & 0 & 0 & 0 & 0 \\
\hline 6 & 0 & 0 & 0 & 0 & 0 & 0 & 0 & 0 \\
\hline 7 & 0 & 0 & 0 & 0 & 0 & 0 & 0 & 0 \\
\hline
\end{tabular}

\section{KESIMPULAN}

- Penerapan point operation image enhancement berupa histogram equalization, contrast stretching, brigthening serta gamma correction pada citra penampung mampu meningkatkan kapasitas pesan.

- Kapasitas pesan pada steganografi DCT sekuensial lebih besar dibandingkan dengan steganografi DCT F5 baik sebelum penerapan POIE maupun setelah penerapan POIE. Kualitas citra stego pada steganografi DCT F5 lebih baik dibandingkan dengan 
steganografi DCT sekuensial baik sebelum penerapan POIE maupun setelah penerapan POIE.

- Baik steganografi DCT F5 maupun steganografi DCT sekuensial sama-sama tidak memiliki ketahanan terhadap distorsi pada citra stego.

\section{SARAN}

Diketahui bahwa dalam penelitian yang dilakukan ini masih terdapat kekurangan dan memerlukan penelitian lebih lanjut guna menghasilkan penelitian yang lebih baik lagi. Oleh karena itu pada penelitian selanjutnya diharapkan dapat menggunakan parameter yang lebih banyak lagi. Faktor keamanan merupakan parameter perbandingan yang dapat dilakukan pada penelitian selanjutnya.

\section{DAFTAR PUSTAKA}

[1] Morkel, T.,Eloff, J.H.P dan Olivier, M.S., 2005, An Overview of Image Steganography, Proceedings of the Fifth Annual Information SecuritySouth Africa Conference, Vol 2, No 3, June, pp.103-112.

[2] Walia, E., Jain, P. dan Navdeep., 2010, An Analysis of LSB \& DCT based Steganography, Global Journal of Computer Science and Technology, Vol 10, Issue 1 (Ver 1.0), 4-8.

[3] Roy,R., Changder,S. Sarkar, A. dan Debnath,N.C, 2013, Evaluating Image Steganography Techniques: Future Research Challenges, Jurnal of IEEE, pp 309-314.

[4] Reddy,V.L., Subramanyam, A., dan Reddy,C.P., 2011, Steganography + JPEG, International Journal of Computer Graphics., Vol. 2, no. 1, pp. 31-42.

[5] Westfeld, A., 2001, F5-A Steganographic Algorithm: High capacity despite better steganalysis, Proc. 4th International Workshop on Information Hiding , Springer, vol. 2137, pp. 289-302.

[7] Rajagopal, G.dan Santhi, K., 2013, Contrast Enhancement Using Bi-Histogram Equalization With Brightness Preservation., International Journal of Computer Trends and Technology (IJCTT), Vol. 4 Issue5-May 2013, pp. 1010-1014.

[8] Sajedi, H dan Jamzad, M., 2012, BSS: Boosted steganography scheme with cover image preprocessing, International Journal of Expert Systems with Applications available at ScienceDirect, pp. 7703-7710.

[9] Sawant, H.K dan Deore, M., 2012, A Comprehensive Review of Image Enhancement Techniques, International Journal of Computer Technology and Electronics Engineering (IJCTEE), pp. 39-44.

[10] Patel,H., dan Dave, P., 2012, Steganography Technique Based on DCT Coefficients , International Journal of Engineering Research and Applications (IJERA), Vol. 2, Issue 1, Jan-Feb 2012, pp.713-717.

[11] Huang,F., Huang, J., dan Shi,Y.Q., 2012, New Channel Selection Rule for JPEG Steganography, IEEE Transaction On Information Forensics and Security.,, Vol. 7, No. 4, pp. 1181-1191.

[12] Murwantini, S., 2007, Kajian Penyimpanan Data pada Media Citra (Steganografi) menggunakan Metode DCT, Tesis, Program Studi Teknik Elektro UGM,Yogyakarta.

[13] Fridrich, J.,Goljan, M dan Hogea, D., 2002, Steganalysis of JPEG Images Breaking The Algorithm, http://www.ws.binghamton.edu/fridrich/Research/f5.pdf, diakses 13 Januari 2013.

IJCCS Vol. 10, No. 1, January 2016 : 35 - 46 